\title{
Clinicopathological profile of patients with up-front metastatic breast cancer: a study from North East India
}

\author{
Mahanta Neelakshi', Deka Hitesh ${ }^{2}$, Kalita NK ${ }^{3}$, Niharika Kutum ${ }^{4}$, Lokkur PP', Ali AS
}

Received on $7^{\text {th }}$ April 2020; editorial approval on $5^{\text {th }}$ May 2020

\begin{abstract}
Introduction: Breast cancer is the most common cancer in Indian females and approximately $5-10 \%$ present with upfront metastasis and 20-30\% patients develops metastasis during follow up, but still limited data is available regarding the same. Objectives: To study the clinicopathological profile of breast cancer patients presenting with up-front metastasis. Materials and methods: This is a retrospective study of Metastatic Breast Cancer (MBC) patients who attended the Medical Oncology Department of State Cancer Institute, Guwahati. In the study, we reviewed the records regarding clinical and histological profile, receptor status and site of metastasis of breast cancer patients presented with up-front metastasis from January 2019 to December 2019. Results: Total of 65 cases of MBC were studied. The average age of presentation was 46 years (range 22-70 years) with an average duration of symptoms 8 months (range 3-18 months). Male and Female ratio was 2:63. MBC was common in postmenopausal (52.38\%) and Para 2 (48.7\%) women. 41.53\% of patients were at performance status 1 at presentation. In the histopathological study, ductal carcinoma was the most common (93.85\%) pathological type with Nottingham grade II (60\%) was the most common. Baseline receptor status suggested that $56.92 \%$ were hormone receptor [HR] positive, $40 \%$ were human epidermal growth factor-2 [Her2] neu positive and $18.46 \%$ were triple-negative breast cancer [TNBC]. Various sites of metastasis were visceral only (20\%), bone (40\%), combined bone and visceral (36.92\%), nonregional lymph nodes (15.38\%) and brain (4.61\%). Conclusion: $M B C$ is common in younger patients with bony metastasis being the commonest site of metastasis.
\end{abstract}

Keywords: Histopathological profile; receptor status; sites of metastasis.

\section{INTRODUCTION}

Breast cancer is one of the earliest known malignancies of mankind documented way back in $6^{\text {th }}$ century as "Divine punishment". ${ }^{1}$ Now in the $21^{\text {st }}$ century breast cancer has become the most commonly occurring cancer in women both in developed and developing countries like India and the second most common cancer overall. According to GLOBOCAN 2018 statistics, there were over 2 million new cases of breast cancer in 2018 worldwide. ${ }^{2}$ The incidence of breast cancer is increasing in the developing countries due to increased life expectancy, increased urbanization and adoption of western lifestyles. Indian Council for Medical Research [ICMR] reports 1.5 lakh new breast cancer cases in India per year. As reported in the Western literature, ${ }^{3}$ approximately $5-10 \%$ of patients present with up-front metastasis and 20$30 \%$ of patients develop metastasis during follow up. The scenario is quite different in India with approximately 5-25\% breast cancer patients still present in metastatic stage. ${ }^{4}$ An average age of 50-53 years is reported for breast cancer patients in various population-based studies done in India. ${ }^{5,6}$ Breast cancer is considered to be a systemic disease because it can metastasize to distant sites in early stages even before
Address for Correspondence:
${ }^{1}$ Associate Professor and Head of the Department
Mobile: +919864016221
Email: neelakshimahanta@gmail.com
${ }^{2}$ Fellow (Corresponding author)
Mobile: +91757707554
Email: dekahitesh89@gmail.com
${ }^{3}$ Registrar, ${ }^{4}$ Fellow, ${ }^{5}$ Junior consultant, ${ }^{6}$ Senior Resident
Department of Medical Oncology
State Cancer Institute, Guwahati, Assam, India

Cite this article as: Mahanta Neelakshi, Deka Hitesh, Kalita NK, Niharika Kutum, Lokkur PP, Ali AS. Clinicopathological profile of patients with up-front metastatic breast cancer: a study from North East India. Int J Health Res Medico Leg Prae 2020 July;6(2):10-14. DOI 10.31741/ijhrmlp.v6.i2.2020.2 
the primary tumour become clinically evident so the management approach and treatment strategy directed only to the primary tumour will not be sufficient. The management and prognosis of breast cancer are largely based on luminal classification i.e. molecular subtype, HR [ER and/or PR] and /or Her2neu status of the patient, visceral versus non-visceral metastasis, performance status [PS] and age of the patient. Hormonal therapy, targeted therapy and chemotherapy are the various modes of treatment apart from surgery, radiotherapy depending on patient profile. Targeted therapy will be more beneficial if we know the receptor targets and if the patients present at an early stage of the disease. State Cancer Institute, Guwahati is one of the tertiary care oncology centres of North Eastern region of India providing comprehensive oncology services to the patients from entire $\mathrm{NE}$ regions however data regarding the $\mathrm{MBC}$ patients is still limited from this part of the country. With the knowledge from the existing literature, we have aimed to evaluate the clinical and pathological characteristics of our breast cancer patients presenting with up-front metastasis so that it gives us an idea of the clinical spectrum of MBC patients from this part of the country and the pathological and molecular profile of these patients which would imply the treatments and outcomes.

\section{MATERIALS AND METHODS}

The present study is a hospital-based retrospective study carried out on 65 breast cancer patients attended Department Medical Oncology at State Cancer Institute, Guwahati presenting with features of up-front metastasis during one year period from January 2019 to December 2019.

During the study periods, 389 breast cancer patients were registered in the OPD services of State Cancer Institute, Guwahati. Out of these, 73 patients presented with up-front metastasis and 65 patients were considered for analysis and 8 patients were excluded because of incomplete medical records or lost to follow up after $1^{\text {st }}$ visit.

We retrieved the data regarding patient's characteristics [age, sex, menopausal status, PS and duration of symptom], pathological features, receptor status [ER/PR/Her2neu], molecular subtype (Table 1) and metastatic profile by reviewing the patient's file from the medical records department.

Table 1 Luminal classification [Molecular subtypes] of breast cancer $^{7}$

\begin{tabular}{|l|l|l|l|l|}
\hline & $\begin{array}{l}\text { Luminal } \\
\text { A/B }\end{array}$ & $\begin{array}{l}\text { Her2 } \\
\text { enriched }\end{array}$ & $\begin{array}{l}\text { Basal } \\
\text { type }\end{array}$ & $\begin{array}{l}\text { Luminal/ } \\
\text { Her2 }\end{array}$ \\
\hline $\begin{array}{l}\text { ER/PR } \\
\text { expression }\end{array}$ & + & \pm & - & + \\
\hline $\begin{array}{l}\text { Her2 } \\
\text { amplification }\end{array}$ & \pm & + & - & + \\
\hline
\end{tabular}

Abbreviations: ER, estrogen receptor; PR, progesterone receptor; Her2, human epidermal growth factor receptor 2 .

Menopausal status is assessed from clinical history as the permanent cessation of menstrual periods, i.e. when a woman has not had any menstrual bleeding for a year without any other obvious pathological or physiological cause.

Performance status is assessed using Eastern Cooperative Oncology Group performance status [ECOG PS] grading as shown in Table 2.

\section{Table 2 ECOG PS 8}

\begin{tabular}{|l|l|}
\hline Grade 0 & $\begin{array}{l}\text { Fully active, able to carry on all pre-disease } \\
\text { performance without restriction }\end{array}$ \\
\hline Grade 1 & $\begin{array}{l}\text { Restricted in physically strenuous activity, but } \\
\text { ambulatory and able to carry out work of light } \\
\text { and sedentary nature }\end{array}$ \\
\hline Grade 2 & $\begin{array}{l}\text { Ambulatory and capable of all self-care but } \\
\text { unable to carry out any work activities. Up } \\
\text { and about more than 50\% of working hours }\end{array}$ \\
\hline Grade 3 & $\begin{array}{l}\text { Capable of only limited self-care, confined to } \\
\text { bed or chair more than 50\% of working hours }\end{array}$ \\
\hline Grade 4 & $\begin{array}{l}\text { Completely disabled. Cannot carry on any self- } \\
\text { care. Confined to a bed or chair }\end{array}$ \\
\hline Grade 5 & Dead \\
\hline
\end{tabular}

HR and Her2neu status was tested by standard immunohistochemistry [IHC] methods. IHC testing was performed in the paraffin-embedded breast tissue blocks [true cut or excisional biopsy specimen] stained with monoclonal antibodies. Allred scoring system was used for reporting the HR status. Allred or H score of 3 or more was considered as positive. ${ }^{9}$ Her2neu status was tested as per the American Society of Clinical Oncology [ASCO]guidelines. ${ }^{10}$ A score of $3+$ was considered positive and $2+$ was considered equivocal and $1+$ as negative. All $2+$ results of her 2 neu were confirmed by fluorescence in situ hybridization [FISH] amplification. Histologic type and grade were assessed according to the World Health Organization [WHO] standard and Nottingham grading respectively. ${ }^{11}$ A metastatic workup was done using ${ }^{18} \mathrm{~F}-\mathrm{NaF}$ bone scan, CT scan of thorax and abdomen, magnetic resonance imaging [MRI] of brain or FDG positron emission tomography [PET] CT scan. Bone only, visceral [lung, liver, adrenal], brain and non-regional lymph nodes [LN] were recorded for the site of metastasis. Patient with 5 or fewer metastases involving 1 or 2 organs is considered to have the oligometastatic disease.

\section{RESULTS}

The median age of presentation was 46 years [range, 22 to 70 years] and the median duration of symptoms was 8 months [range, 3-18 months]. The male-female ratio was $2: 63$. MBC was common among postmenopausal women $[\mathrm{N}=33,52.38 \%] .7$ patients $[11.11 \%]$ were nulliparous and 20 patients [31.74\%] had a history of use of some form of hormonal contraceptive medication at some part of their reproductive life. 11 patients $[16.92 \%]$ had a family history of malignancy and 5 of them were specific for breast cancer (Table 3). 
Table 3 Clinical characteristics of MBC patients

\begin{tabular}{|l|l|}
\hline Parameters & Number [\%] \\
\hline Total number of patients Included & 65 \\
\hline Median age at presentation (years) & 46 years [range, 22-70] \\
\hline $\begin{array}{l}\text { Average duration of symptoms } \\
\text { in months }\end{array}$ & 8 months [range, 3-18] \\
\hline Sex: $(\mathrm{n}=65)$ & \\
\hline Male & 2 \\
\hline Female & 63 \\
\hline Menopausal status: $(\mathrm{n}=63)$ & \\
\hline Premenopausal & $30[47.62 \%]$ \\
\hline Postmenopausal & $33[52.38 \%]$ \\
\hline ECOG PS: $(\mathrm{n}=65)$ & \\
\hline PS 0 & $8[12.3 \%]$ \\
\hline PS 1 & $27[41.53 \%]$ \\
\hline PS 2 & $21[32.30 \%]$ \\
\hline PS 3 & $7[10.76 \%]$ \\
\hline PS 4 & $2[3.76 \%]$ \\
\hline
\end{tabular}

Ductal carcinoma was the most common [93.85\%] histologic type and Nottingham grade II being the most common grade in $\mathrm{MBC}$ patients (Table 4).

Table 4 Pathological profile

\begin{tabular}{|l|l|}
\hline Parameter & Number [\%] \\
\hline Histologic type & \\
\hline Ductal Carcinoma & $61[93.85 \%]$ \\
\hline Lobular Carcinoma & $3[4.61 \%]$ \\
\hline Others & $1[1.52 \%]$ \\
\hline $\begin{array}{l}\text { Histologic Grade } \\
\text { [Nottingham Grade] }\end{array}$ & \\
\hline Grade I & $3[4.61 \%]$ \\
\hline Grade II & $39[60 \%]$ \\
\hline Grade III & $23[35.85 \%]$ \\
\hline
\end{tabular}

HR status [ER and/or PR] were positive in 37 patients. Her2neu was positive in 21 patients and 12 patients were found to have TNBC (Figure 1).

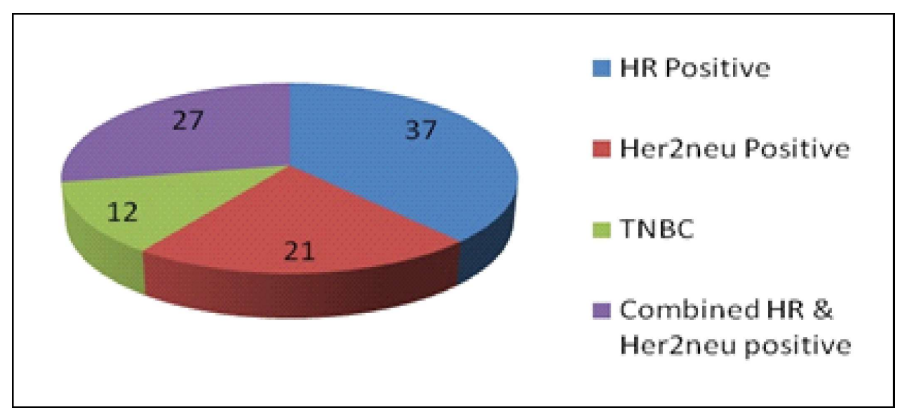

Figure 1 Baseline receptor status
Abbreviations: HR, Hormone receptor; Her2 neu, Human epidermal growth factor receptor 2; TNBC, triple-negative breast cancer.

The most common site of metastasis was bone [40\%], followed by combined bone and visceral metastasis in $36.92 \%$, only visceral metastasis in $20 \%$, non-regional LNs in $15.38 \%$ and brain in 3 patients (Figure 2). In visceral metastasis, the liver was most frequently involved [60.87\%] followed by lung and adrenal.

Overall bony metastasis was the most common site of metastasis irrespective of receptor status. The vertebrae were the most common bone involved by metastasis. 25 patients [38.46\%] had the oligometastatic disease. Patients with TNBC presented at an earlier age [37 years, range $22-55$ years] and most are premenopausal [66.67\%] with poor PS [ECOG PS 2-3] and had multiple sites metastasis at presentation.

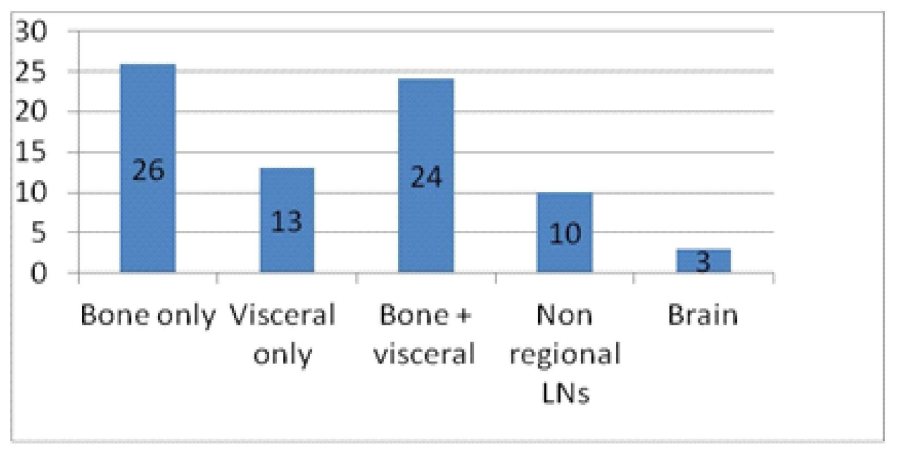

Figure 2 Sites of metastasis

\section{DISCUSSION}

Breast cancer is the most common cancer in women worldwide, with the widely variable incidence among countries and regions. As per the ICMR Population-based Cancer Registry data, breast cancer is the most common cancer among women in urban registries and second most common cancer in women after cancer of the uterine cervix in rural registries in India. , $^{5}$

In general, breast cancer has been reported to occur a decade earlier in Indian patients compared with their Western counterparts. Although the majority of patients with breast cancer in Western countries are postmenopausal and in their $60 \mathrm{~s}$ and $70 \mathrm{~s}$, the picture is quite different in India, with premenopausal patients constituting approximately $50 \%$ of all patients. ${ }^{4}$ More than $80 \%$ of Indian patients are younger than 60 years of age. The average age of patients with breast cancer has been reported to be 50 to 53 years in various population-based studies done in different parts of the country. ${ }^{5,6}$ In the present study we have documented a median age of 46 years [range, 22 to 70 years]. In studies from Western countries, the median age of presentation was 55 to 60 years. $^{12,13}$ In our study we found the average age of presentation was 46 years which is almost similar to the study by Gogia A et al. ${ }^{14}$ The present study documented that approximately $47.62 \%$ of patients were premenopausal and $52.38 \%$ were postmenopausal, whereas studies from the 
Western world have documented $70 \%$ to $80 \%$ patients are postmenopausal at presentation. ${ }^{12,13}$

In this study, HR was positive in $56.92 \%$ of patients; previous studies documented approximately $49 \%$ to $68 \%$ (Table 5). The incidence of TNBC in the present study is $18.46 \%$ which is almost similar to the study by Kunikullaya SU et al. ${ }^{15}$

Table 5 Comparison of the present study with previous studies

\begin{tabular}{|l|l|l|l|l|}
\hline Parameters & Dafni et al & \multicolumn{1}{|c|}{ Giordano et al $^{\mathbf{1 3}}$} & Gogia A et al $^{\mathbf{1}}$ & Present study \\
\hline Total no of patients & 364 & 105 & 375 & 65 \\
\hline Duration of study & $2003-2006$ & $1995-2000$ & $2012-2018$ & 1 year \\
\hline Age at presentation [years] & $60[27-84]$ & $49[26-73]$ & $49[22-80]$ & $46[22-70]$ \\
\hline Menopausal status: & & & & \\
\hline Premenopausal & $19.5 \%$ & $48 \%$ & $39.8 \%$ & $47.69 \%$ \\
\hline Postmenopausal & $80 \%$ & $52 \%$ & $60 \%$ & $52.69 \%$ \\
\hline Receptor Status: & & & & \\
\hline HR positive & $68 \%$ & $49 \%$ & $61.4 \%$ & 56.92 \\
\hline Her2neu positive & - & - & $38.6 \%$ & $40 \%$ \\
\hline TNBC & - & - & - & $18.46 \%$ \\
\hline Site of metastasis: & & & 26.7 & \\
\hline Bone only & $50 \%$ & $28 \%$ & $58.4 \%$ & $40 \%$ \\
\hline Visceral Only & $72.5 \%$ & $37 \%$ & $5.6 \%$ & $20 \%$ \\
\hline Non regional LN & $25 \%$ & $30 \%$ & $2.7 \%$ & $15.38 \%$ \\
\hline Brain & - & - & - & $4.61 \%$ \\
\hline Combined bone and visceral & - & - & $36.92 \%$ \\
\hline
\end{tabular}

In patients who had metastasis in this study, $16.71 \%$ presented with up-front metastasis. Common sites of metastasis were bone, lung, liver, lymph nodes and brain. Kennecke et al. ${ }^{16}$ and Smid et al. ${ }^{17}$ in their studies concluded that HR-positive tumours commonly spread to the bone and HR-negative and/or Her2 positive tumours are likely to spread to the viscera; however, in the present study, we have found that bone is a most common site of metastasis irrespective of the receptor status. The liver is the most common site of visceral metastasis [60.7\%]. Park et al. ${ }^{18}$ in his study found out the correlation between the molecular subtype and pattern of distant metastasis and concluded that Her2 over-expression provide aggressiveness to the tumour and commonly associated with brain metastasis. In the present study, we also found that Patients with visceral and brain metastasis commonly have Her2 enriched MBC.

\section{CONCLUSION}

In the study, we have found that the majority of the patients were younger and premenopausal at presentation and in the productive years of their life. Overall receptor status [ER/ $\mathrm{PR} / \mathrm{Her} 2 \mathrm{neu}]$ is positive in $81.54 \%$ patients i.e. quite a large number of patients can be treated with curative intent if they present in early stage and can be prevented from developing metastatic disease. Patients with visceral and brain metastasis is commonly associated with Her2 overexpression so the patients who have her 2 enriched tumour at baseline receptors status assessment need special attention during follow up so that early detection of metastasis is possible and targeted therapy can be considered for them. A quite large number of patients in our study presented in a later stage of disease when the performance status was deteriorating indicating that there is a lack of awareness of the disease in the general population.

Limitation of the study: A limitation in our study is that it was a retrospective study and the duration and study population was less so we advocate for further studies with a large number of patients over a larger duration of the period.

Acknowledgements: We thank our patients who were included in the study and all the faculties and staffs of State Cancer Institute, Guwahati for their support during the study.

Contribution of authors: (1) The article is original with the author(s) and does not infringe any copyright or violate any other right of any third party. (2) The article has not been published (whole or in part) elsewhere and is not being considered for publication elsewhere in any form, except as provided herein. (3) All author(s) have contributed sufficiently in the article to take public responsibility for it and (4) All author(s) have reviewed the final version of the above 
manuscript and approved it for publication.

Ethical clearance: Taken.

Conflict of interest: None declared.

Source of funding: None declared.

\section{REFERENCES}

1. Yalom, Marilyn. A history of breast. New York: Alfred A. Knopf; 1997. p.234.

2. Bray F, Ferlay J, Soerjomataram I, Siegel RL, Torre LA, Jemal A. Global Cancer Statistics 2018: GLOBOCAN estimates of incidence and mortality worldwide for 36 cancers in 185 countries. CA Cancer J Clin 2018 Nov;68(6):394-424.

3. O'Shaughnessy J. Extending survival with chemotherapy in metastatic breast cancer. Oncologist 2005;10 Suppl 3:20-9.

4. Agarwal G, Ramakant P. Breast cancer care in India: The Current Scenario and the Challenges for the Future. Breast Care (Basel) 2008;3(1):21-7.

5. National Cancer Registry Programme: First All India Report: 2001-2002, Chapter 2: Overall planning and methods. 2010. Available from: URL:http:// www.ncdirindia.org/ncrp/ca/ map.aspx

6. National Cancer Registry Programme: First All India Report: 2001-2002, Chapter 4: Minimum incidence rates of cancer [all sites] in districts. 2010. Available from: URL:http:// www.ncdirindia.org/ncrp/ca/ chapter4_1.aspx

7. Perou CM, Sorlie T, Eisen MB, van de Rijn M, Jeffrey SS, Rees CA, et al. Molecular portraits of human breast tumours. Nature 2000 Aug 17;406(6797):747-52.

8. Oken MM, Creech RH, Tormey DC, Horton J, Davis TE, McFadden ET, et al. Toxicity and response criteria of the Eastern Cooperative Oncology Group. Am J Clin Oncol 1982 Dec;5(6):649-55.

9. Harvey JM, Clark GM, Osborne CK, Allred DC. Estrogen receptor status by immunohistochemistry is superior to the ligand-binding assay for predicting response to adjuvant endocrine therapy in breast cancer. J Clin Oncol 1999 May;17(5):1474-81.
10. Wolff AC, Hammond MEH, Allison KH, Harvey BE, Mangu PB, Bartlett JMS, et al. Human epidermal growth factor receptor 2 testings in breast cancer: American Society of Clinical Oncology/College of American Pathologists clinical practice guideline focused update. J Clin Oncol 2018 Jul 10;36(20):2105-22.

11. Elston CW, Ellis IO. Pathological prognostic factors in breast cancer. I. The value of histological grade in breast cancer: experience from a large study with long-term follow-up. Histopathology 1991Nov;19(5):403-10.

12. Dafni U, Grimani I, Xyrafas A, Eleftheraki AG, Fountzilas G. Fifteen-year trends in metastatic breast cancer survival in Greece. Breast Cancer Res Treat 2010 Feb;119(3):621-31.

13. Giordano SH, Buzdar AU, Smith TL, Kau SW, Yang Y, Hortobagyi GN. Is breast cancer survival improving? Cancer 2004 Jan 1;100(1):44-52.

14. Gogia A, Deo SVS, Sharma D, Thulkar S, Kumar R, Malik PS, et al. Clinicopathologic Characteristics and Treatment Outcomes of Patients With Up-Front Metastatic Breast Cancer: Single-Center Experience in India. J Glob Oncol 2019 Mar;5:1-9.

15. Kunikullaya SU, Poddar J, Sharma AD, Patel S. Pattern of distant metastasis in molecular subtypes of carcinoma breast: An institutional study. Indian J Cancer 2017;54(1):327-32.

16. Kennecke H, Yerushalmi R, Woods R, Cheang MC, Voduc D, Speers CH, et al. Metastatic behaviours of breast cancer subtypes. J Clin Oncol $2010 \mathrm{Jul}$ 10;28(20):3271-7.

17. Smid M, Wang Y, Zhang Y, Seiuwerts AM, Yu J, Klijn JG, et al. Subtypes of breast cancer show preferential site of relapse. Cancer Res 2008 May 1;68(9):3108-14.

18. Park HS, Kim S, Kim K, Yoo H, Chae BJ, Bae JS, et al. Pattern of distant metastasis recurrence according to molecular subtypes in Korean women with breast cancer. World J Surg Oncol 2012 Jan 8;10:4. 